\title{
Functional Attributes of Responding T Cells in HCV Infection: The Recent Advances in Engineering Functional Antiviral T Cells
}

\author{
Anna Pasetto · Soo Aleman • Margaret Chen
}

Received: 8 April 2013/Accepted: 5 August 2013/Published online: 18 August 2013

(C) L. Hirszfeld Institute of Immunology and Experimental Therapy, Wroclaw, Poland 2013

\begin{abstract}
Hepatitis C virus (HCV) is one of the major causes of hepatocellular carcinoma (HCC) around the world. HCV promotes characteristics of cancer stem cells and the infected cells are insensitive to apoptotic signals, which lead to persistent antigen stimulation and $\mathrm{T}$ cell exhaustion in the host. In spite of new effective antiviral drugs, new challenges are around the corner as drugresistant viral strains and drug-drug interactions have already been reported. Considering that there are few effective treatments available for HCC, novel immunotherapies to prevent HCC and late stage HCV-related liver diseases should be considered. Given that adoptive immunotherapy with antigen-specific $\mathrm{T}$ lymphocytes has emerged as an effective therapeutic strategy for combating cancer, there is, therefore, reason to examine the possibility of using highly functional HCV-reactive T cells in immunotherapy. This review aims to provide the current understanding of natural $\mathrm{HCV}$ responding $\mathrm{T}$ cells in $\mathrm{HCV}$ infection and to give an update on the novel approaches
\end{abstract}

A. Pasetto

Department of Laboratory Medicine, Karolinska Institutet, Huddinge, Sweden

S. Aleman

Department of Medicine, Karolinska Institutet, Huddinge, Sweden

A. Pasetto $\cdot$ M. Chen $(\square)$

Department of Dental Medicine, Karolinska Institutet, Alfred Nobels Allé 8, 14104 Huddinge, Sweden

e-mail: Margaret.Chen@ki.se

Present Address:

A. Pasetto

Center for Cancer Research, National Cancer Institute,

National Institutes of Health, Bethesda, MD 20892, USA that have the capacity to ex vivo generate functional $\mathrm{T}$ cells for potential adoptive cell therapy. Approaches based on the pMHC tetramer-associated magnetic enrichment, exogenous $\mathrm{HCV} \mathrm{T}$ cell receptor transfer, and induced pluripotent stem cell technologies are described herein. Their potentials as immunotherapeutic against HCV-related diseases are discussed.

Keywords Virus - Hepatitis - Antiviral $\cdot$ T cell receptor . Gene transfer · Immunotherapy

\section{Introduction}

Hepatitis $\mathrm{C}$ virus (HCV) is one of the major causes of chronic liver disease and it is estimated that around 170 million people in the world are infected. The problem with $\mathrm{HCV}$ infection is the persistence of the virus that leads to liver cirrhosis and the increased risk of hepatocellular carcinoma, and today this has become a leading cause for liver transplantation. The available therapy involves a combination of pegylated interferon (IFN)- $\alpha$, ribavirin and, since their introduction in 2011, NS3/4A protease inhibitors for genotype 1 virus (Jacobson et al. 2011). A major challenge is patients who do not respond to treatment, where $\mathrm{HCV}$ genotype 1 (in particular subtype A), advanced fibrosis, high viral load or IL28B SNP non-CC are regarded as important negative baseline factors (Ghany et al. 2011). Given the reported side effects and potential drug-drug interactions, current therapies with direct acting anti-virals (DAAs) against HCV are not approved for several patient groups (decompensated liver cirrhosis, liver transplantation, severe psychiatric illness etcetera) (Sarrazin et al. 2012). Thus, improved interventions for hard-to-treat HCV patients are crucial. 
HCV has adapted several mechanisms to escape host immunity. Many of the viable variants cluster in high-variability regions (e.g., HVR1) of the viral glycoproteins, providing flexibility for adaptation against host humoral immunity. Not only the fact that the access of the epitopes to antibody neutralization sites is concealed by glycosylation sites, the presence of interfering antibodies may also disturb the action of neutralizing antibodies. It was thought earlier that antibodies attributed only a marginal role to the humoral response during HCV infection (Chen et al. 1999; Logvinoff et al. 2004; Netski et al. 2005). However, experimental models have shown that neutralizing antibodies act in a strain- and isolate-specific manner and prevent HCV infection in chimpanzees (Farci et al. 1994, 1996). More recent studies have elegantly shown that improved vaccination strategies employing for instance virus-like particles, pseudotyped for HCV proteins, can trigger broadly neutralizing antibodies in macaques and a human liver-chimeric mouse model (Dorner et al. 2011; Garrone et al. 2011; Giang et al. 2012; Law et al. 2008). Broadly neutralizing antibodies have substantial prophylactic and therapeutic potentials; therefore, they are the holy grail in the development of a prophylactic vaccine to enhance clearance of acute $\mathrm{HCV}$ infections. However, because most chronically infected patients have poor $\mathrm{HCV}$-specific $\mathrm{T}$ cell responses but substantial levels of neutralizing antibodies, therapeutic approaches have mainly focused on enhancing the cellular arm of the adaptive immune response.

A critical property of adaptive immunity is the $\mathrm{T}$ cell memory that instructs the immune system to act more rapidly and effectively upon re-exposure to the same pathogen (Antia et al. 2005). In chronic viral infections, where antigen and/or inflammation persist for many years, various levels of exhaustions have been found in virusspecific $\mathrm{T}$ cells. This immunological phenomenon defined as "T cell exhaustion" was first proposed for chronic lymphocytic choriomeningitis virus infection in mice, and it has also been validated in other chronic viral infections in humans, including the human immunodeficiency virus (HIV), hepatitis B virus, human papilloma virus and HCV (Wherry 2011). Studies have demonstrated that virus-specific $\mathrm{T}$ cell responses play a major role in the outcome of HCV infection (Bowen and Walker 2005; Grakoui et al. 2003; Rehermann and Nascimbeni 2005). It seems clear that a broad and long-lasting $\mathrm{CD}^{+}$and $\mathrm{CD}^{+}{ }^{+} \mathrm{T}$ cell response is required to control $\mathrm{HCV}$, but many additional details remain unclear.

This review presents the main features of $\mathrm{HCV}$ responding $\mathrm{T}$ cells during natural infection, and gives an introduction over recent new strategies on ex vivo generation of highly functional antigen-specific $\mathrm{T}$ cells that may have an impact for adoptive cell therapies of $\mathrm{HCV}$ infection.

\section{Responding T Cells in HCV Infection}

Acute HCV Infection with Spontaneous Resolution

Both $\mathrm{HCV}$-specific $\mathrm{CD} 4^{+}$and $\mathrm{CD}^{+}{ }^{+} \mathrm{T}$ cells are determinant for the outcome of $\mathrm{HCV}$ infection. At the time of clinical symptoms during acute $\mathrm{HCV}$ infection, extensive proliferation of $\mathrm{HCV}$-specific $\mathrm{CD}^{+}$and $\mathrm{CD}^{+} \mathrm{T}$ cells with concomitant interleukin (IL)- 2 and IFN- $\gamma$ production has often been detected in the blood of patients who later overcome the infection. These responses emerge four to 6 weeks after infection targeting multiple viral epitopes and are sustained for many years after viral resolution. In this early phase, the activated $\mathrm{CD}^{+}$cytotoxic $\mathrm{T}$ lymphocyte (CTL) populations may acquire a "stunned" phenotype, in which they temporarily fail to proliferate and secrete IFN- $\gamma$ but recover as the HCV viremia declines (Lechner et al. 2000; Rehermann 2009; Thimme et al. 2001). A rapid emergence of $\mathrm{T}$ helper responses in concert with $\mathrm{CTL}$ responses in the early disease often demonstrates a strong and persistent CTL response in resolving acute $\mathrm{HCV}$ infection. As for other viral infections, an efficient $\mathrm{T}$ cell response with poly-functionality has also been shown to correlate with resolution of $\mathrm{HCV}$ infection (Abdel-Hakeem et al. 2010; Badr et al. 2008; Ciuffreda et al. 2008; Zimmerli et al. 2005). According to the definition of antigen-experienced T cells (Sallusto et al. 2004), the functional attributes of HCV-specific effector T cells in these patients resemble $\mathrm{T}$ cells that derive from the naïve and memory $\mathrm{T}$ cell $\left(\mathrm{T}_{\mathrm{CM}}\right.$ : central memory, or $\mathrm{T}_{\mathrm{EM}}$ : effector memory) pools. As illustrated in Fig. 1, the virus-specific $\mathrm{T}$ cells at this stage are able to differentiate into highly effective polyfunctional effector $\mathrm{T}$ cells that have substantial capacity to secrete antiviral cytokines, capable of homing to infected tissue and proliferating to drive the elimination of infected cells. CD ${ }^{+}$ CTLs are essential for an effective immune response against all viral infections (Appay et al. 2008) and it is known that virus-specific CTLs mediate viral suppression by three main pathways using: (1) antiviral mechanisms of IFN- $\gamma$; (2) lysis of infected cells via Fas-FasL interaction; and (3) lysis of target cells by delivery of granzyme and perforin. Albeit in the case for $\mathrm{HCV}$, the non-cytolytic mechanism of viral clearance has been discussed as an alternative pathway in viral hepatitis since infected cells could be cured instead of killed and, therefore, cause less liver injury (Guidotti and Chisari 2001; Guidotti et al. 1999).

\section{Chronic Persistent HCV Infection}

In contrast to patients who spontaneously resolve their $\mathrm{HCV}$ infection, those who progress to the chronic phase of infection show an reduced $\mathrm{HCV}$-specific $\mathrm{CD}^{+}{ }^{+} \mathrm{T}$ cell response relatively early in the acute phase of infection. In 


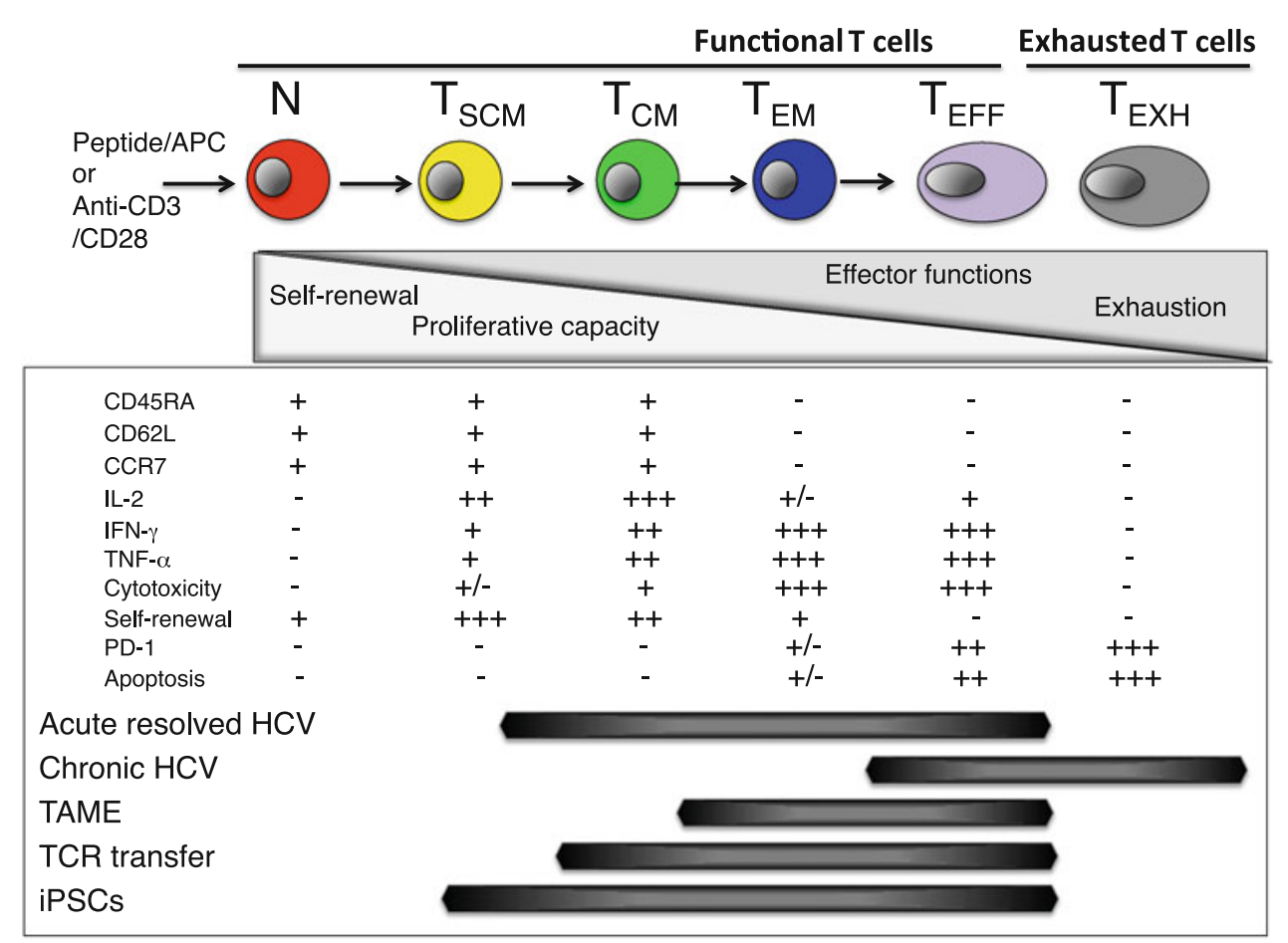

Fig. 1 Generalized model of $\mathrm{T}$ cell differentiation by natural HCV infection (acute resolved or chronic infection), and cell technologies that are based on tetramer-associated magnetic enrichment (TAME), TCR gene transfer or induced pluripotent stem cells (iPSCs). Signals from cognate peptide/MHC/antigen-presenting cell (APC) or antiCD3/CD28 cross-linking trigger a clonal expansion and differentiation of naïve $(\mathrm{N})$ antigen-specific $\mathrm{T}$ cells. This leads to differentiation of $\mathrm{T}$ cell subsets that differ in their capacity for proliferation and effector functions. An effective elimination of $\mathrm{HCV}$-infected cells

patients developing chronic infection, virus-specific $\mathrm{CD} 8^{+}$ $\mathrm{T}$ lymphocytes are reported as abnormal in terms of their synthesis of antiviral cytokines and lytic activity. In addition, it is noted later on in the chronic phase of infection that most of the $\mathrm{T}$ cell responses were detectable only in the liver but not in peripheral blood, indicating $\mathrm{T}$ cell accumulation and enrichment at the site of disease. In spite of this, only a small fraction, as low as $0-5 \%$, of CD8 ${ }^{+}$ liver $\mathrm{T}$ cells appears to be $\mathrm{HCV}$-specific (mean: $0.4 \%$ ) (Neumann-Haefelin et al. 2008; Spangenberg et al. 2005). Thus, it seems that the majority of $\mathrm{CD}^{+} \mathrm{T}$ cells in the liver are not $\mathrm{HCV}$-specific in chronically infected patients. Based on these findings, $\mathrm{HCV}$-specific $\mathrm{T}$ cells are thus referred to as dysfunctional and lack both poly-functionality and multiple target specificity (Kim and Ahmed 2010; Klenerman and Thimme 2012). The basis for this is thought to be the continuous antigen stimulation as a consequence of the chronic $\mathrm{HCV}$ infection, which drives the HCV-specific $\mathrm{T}$ cells into exhaustion. Considering that up to $30 \%$ of the liver could be infected with $\mathrm{HCV}$, adaptive $\mathrm{T}$ cell immunity may not be sufficient in the majority of patients. This allows development of viral requires highly functional $\mathrm{HCV}$-specific $\mathrm{T}$ cells capable of polycytokine secretion and cytolysis that are characteristics of effector $\mathrm{T}$ cells $\left(\mathrm{T}_{\mathrm{EFF}}\right)$. In contrast, a chronic infection with persistent antigen stimulation leads to $\mathrm{T}$ cell exhaustion where exhausted $\mathrm{T}$ cells $\left(\mathrm{T}_{\mathrm{EXH}}\right)$ are driven to terminal differentiation and ultimately deletion. Highly functional $\mathrm{T}_{\mathrm{EFF}}$ can be engineered using strategies that rely on the proliferative capacity of different progenitor $\mathrm{T}$ cell subsets: the effector memory $\left(\mathrm{T}_{\mathrm{EM}}\right)$, central memory $\left(\mathrm{T}_{\mathrm{CM}}\right)$ and stem cell memory $\mathrm{T}$ cells $\left(\mathrm{T}_{\mathrm{SCM}}\right)$

variants known as "viral escape mutants", a key viral mechanism that further supports the persistent infection. As illustrated in Fig. 1, exhausted T cells represent terminally differentiated effector $\mathrm{T}$ cells; functional impairment includes limited capacity to (1) produce antiviral cytokines, (2) kill the target cells, (3) proliferate to self-renew themselves and (4) express inhibitory receptors. It is known that $\mathrm{T}$ cell inhibitory receptors, such as PD-1, play a major role in $\mathrm{CD}^{+} \mathrm{T}$ cell exhaustion and may drive the effector cells to full exhaustion with ultimately $\mathrm{CD} 8^{+} \mathrm{T}$ cell depletion at the end (Wherry 2011). Attempts to block the PD-1/PD-L1 pathway led only to partial restoration of $\mathrm{T}$ cell function and furthermore it was found that $\mathrm{HCV}$-specific $\mathrm{CD} 8^{+} \mathrm{T}$ cells with a very high expression of PD-1 were highly susceptible to apoptosis (Radziewicz et al. 2007, 2008), and were refractory to PD-1/PD-L1 blockade especially in the liver (Nakamoto et al. 2008). Recent work additionally indicates that PD-1 is not the only inhibitory receptor involved in $\mathrm{T}$ cell exhaustion but there appears to be a more complex network of inhibitory receptors including 2B4 and CD160 KLRG1, CTLA-4 and Tim-3 that all can contribute to $\mathrm{T}$ cell dysfunction in chronic $\mathrm{HCV}$ infections 
(Klenerman and Thimme 2012). Furthermore, mechanisms contributed by $\mathrm{T}$ regulatory cells and viral escape are operational and favor the persistence of $\mathrm{HCV}$. Of note, though $\mathrm{HCV}$ is prone to viral escape, it has been suggested that viral escape may not be a universal mechanism and in fact is limited by fitness cost, for example by the inability to tolerate mutations within highly constrained epitopes (Klenerman and Thimme 2012).

\section{Antigen Responding T Cells in Adoptive Cell Transfer Immunotherapy}

Adoptive cell transfer (ACT) immunotherapy of T cells has emerged as a promising advance in cancer immunotherapy. As a therapy to treat cancer ACT relies on the natural ability of $\mathrm{CD}^{+} \mathrm{T}$ cells to attack tumors for example (Restifo et al. 2012). Similar to chronic viral infections, the resilient persistence of tumor growth also causes $\mathrm{CD}^{+} \mathrm{T}$ cells to become both exhausted and senescent (Klebanoff et al. 2006). In ACT, tumor-specific lymphocytes either harvested from a patient's tumor or genetically modified to confer tumor specificity are prepared and infused back into the same patient (Fig. 2). Remarkably, up to $72 \%$ of patients with advanced stage IV melanoma have shown an objective clinical response to their metastatic disease (Restifo et al. 2012). Recent studies have also indicated that transfer of less-differentiated memory or stem cell-like $\mathrm{CD}^{+} \mathrm{T}$ cells correlates with a more robust eradication of the tumor (Klebanoff et al. 2011; Wang et al. 2012). Considering that features of responding $\mathrm{T}$ cells in cancer and chronic infection share great resemblance, such as functional impairment and an immunosuppressive environment, it is interesting to learn that curative treatment for tumors has advanced considerably since the introduction of ACT using tumor-responding $\mathrm{T}$ cells (Restifo et al. 2012). In the light of clinical and translational tumor studies, we summarize below some recent advances by which the production or enrichment of functional HCV-specific $\mathrm{T}$ cells with therapeutic implications has been shown to be feasible.

\section{Recent Advances in the Generation of Highly Functional HCV Responding T Cells}

\section{Enrichment by pMHC-I Tetramer}

Based on theoretical extrapolations from animal studies, the adult human may have up to $3 \times 10^{11}$ naïve phenotype T cells. Alanio et al. (2010) and Schmidt et al. (2011) proposed to enrich functional and active virus-specific $\mathrm{CD}^{+} \mathrm{T}$ cells directly from the naïve pool of antigenspecific precursors because the human $\mathrm{T}$ cell repertoire is already equipped with a substantial range of antigen-specific $\mathrm{T}$ cells. Using an enrichment protocol based on $\mathrm{pMHC}$ class I tetramer technology referred as tetramer-associated magnetic enrichment (TAME) (Alanio et al. 2010), both groups were able to successfully enrich HCV-specific CTLs captured by the NS3 $1406-1415$ pMHC tetramer from peripheral blood cells of healthy blood donors. As expected, the enriched $\mathrm{T}$ cells displayed a naïve phenotype, including high surface expression of CD45RA, CD27 and CCR7 and low expression of CD11a (Schmidt et al. 2011). The captured HCV-specific $\mathrm{T}$ cells could further be matured and expanded after stimulation with autologous
Fig. 2 Current concepts of adoptive cell therapy $(A C T)$ and $\mathrm{T}$ cell modification. Patient's own $\mathrm{T}$ cells are modified in vitro to increase or acquire targetspecific receptors that provide them ability to eliminate target cells

\section{Different sources of target-specific receptors}

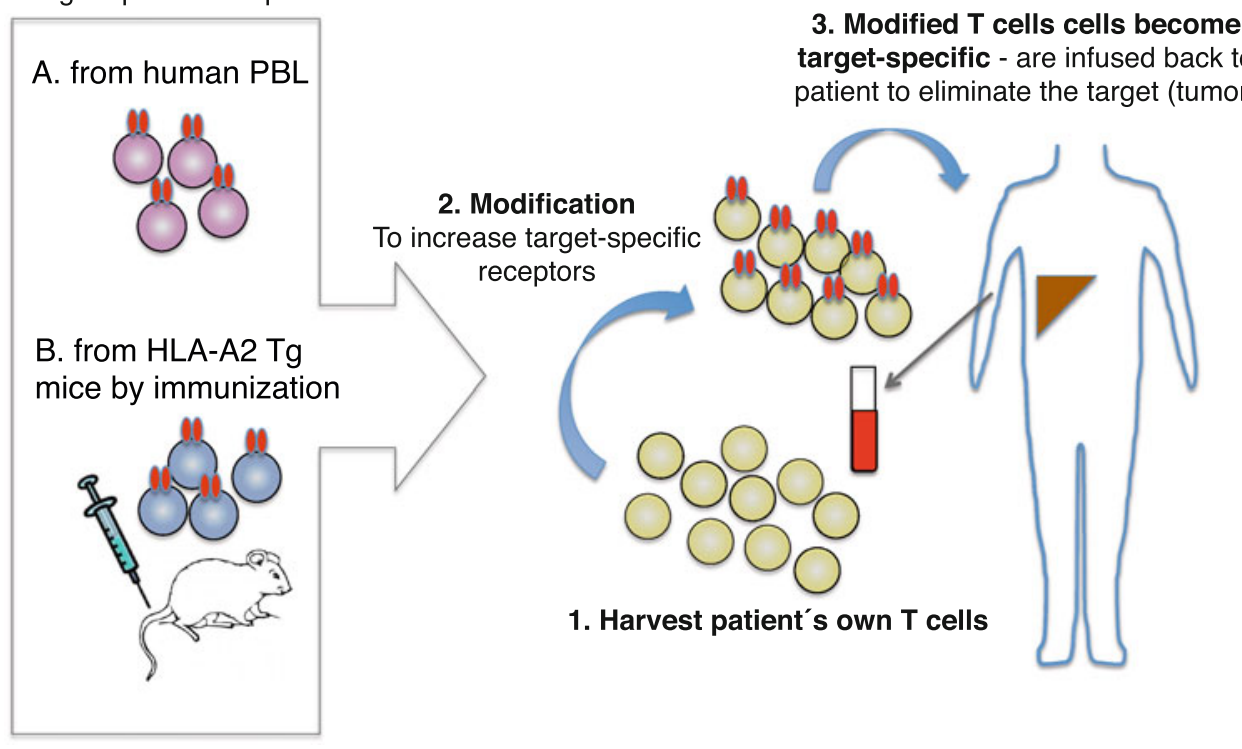


dendritic cells loaded with $\mathrm{NS}_{1406-1415}$ peptide. Importantly, despite that $\mathrm{T}$ cells originate from $\mathrm{HCV}$-negative blood donors, the expanded $\mathrm{T}$ cells displayed a robust antiviral efficacy and were able to inhibit the replication of $\mathrm{HCV}$ replicon on $\mathrm{Huh} 7_{\mathrm{A} 2} \mathrm{HCV}$ hepatoma cells pulsed with the cognate viral peptide (Schmidt et al. 2011). In summary, this approach allowed a rapid isolation of highly functional and proliferative $\mathrm{HCV}$-specific $\mathrm{T}$ cells from blood donors and the possibility to expand them with autologous dendritic cells to drive them into effector memory $\mathrm{T}$ cells that could give rise to highly functional $\mathrm{T}$ cells. Thus, it has substantial implications for adoptive $\mathrm{T}$ cell therapy for HCV patients.

\section{Transfer of Exogenous T Cell Receptor}

This approach relied on $\mathrm{T}$ cell receptor (TCR) transfer by which antigen specificity could be transferred from one $\mathrm{T}$ cell to another through gene transfer. TCR transfer has led to the generation of a number of TCR transgenic and retrogenic animal models for viral hepatitis research (Bettini et al. 2012; Chen et al. 2000, 2004, 2005). As a result and based on a similar principle, TCR-redirected $\mathrm{T}$ cells have also emerged as a new possibility to treat tumor patients (Restifo et al. 2012). In the case of HCV, several $\alpha \beta$ TCRs have been cloned from human and mouse $\mathrm{CD}^{+} \mathrm{T}$ cell lines that are specific to HLA-A2-restricted immunodominant CTL epitopes within the HCV NS3 and NS5A viral proteins (Callender et al. 2006; Pasetto et al. 2012a, b; Zhang et al. 2010). The retroviral-mediated vector technology was utilized to transfer new TCRs (isolated from HCV patients or HCV vaccinated HLA-transgenic mice) to healthy $\mathrm{T}$ cells from blood donors, as well as from HCVinfected individuals. To date, HCV TCRs with specificity to the immunodominant HLA-A2 restricted CTL epitopes NS3 1073-1081, NS3 1406-1415 or NS5A 1992-2000 have been identified and successfully restored on human $\mathrm{T}$ cells. By this approach, the modified recipient $\mathrm{T}$ cells acquired ability to respond not only to HCV peptide-loaded target cells but also to $\mathrm{HCV}$ replicon-positive hepatoma cells directly without having to pulse them with exogenous HCV peptide. In these studies, HCV TCR-modified T cells recognized $\mathrm{HCV}$ target cells with a poly-functional response (IFN- $\gamma$, TNF- $\alpha$ and IL- 2 production and CD107 $\alpha$ up regulation). Pasetto et al. (2012a, b) further demonstrated that HCV TCR-redirected $\mathrm{T}$ cells effectively inhibited $\mathrm{HCV}$ replication on $\mathrm{HCV}$ replicon cells $\left(\mathrm{HCV}^{+} \mathrm{HLA}-\mathrm{A2}^{+}\right.$Huh-7 hepatoma cells) and that this inhibition could utilize the cytolytic or non-cytolytic mechanism. In this regard, the cytolytic mechanism used by the high avidity NS3-specific T cells (TCR H4 or TCR F8) was highly sensitive to its viral peptide target and they are highly poly-functional. Elimination of $\mathrm{HCV}$ replicon by such $\mathrm{T}$ cells was associated with cellular death of $\mathrm{HCV}$ replicon cells, which is in sharp contrast to the low avidity NS5A T cells (TCR 19 or TCR 69) that display features resembling non-cytolytic CTLs in their response to HCV replicon cells. It was shown that NS5A T cells are able to spare the infected cells from cell death compared to the high avidity NS3 T cells. In contrast, NS5A T cells showed a preference to IFN- $\gamma$ secretion and no sign of CD107a degranulation; though the inhibition of HCV RNA replication was rapid and effective, the sign of cell death or cell damage was limited.

Even though cytolytic/high avidity TCRs may be more effective in eliminating $\mathrm{HCV}^{+}$target cells, there are benefits in acquiring non-cytolytic $\mathrm{T}$ cells, as it may spare the host from unwanted tissue damage by having less hepatotoxic potentials (Pasetto et al. 2012a). Adding antigenspecific low avidity $\mathrm{T}$ cells might be an advantage when reconstituting a multi-specific antiviral $\mathrm{T}$ cell response when the potential overkilling of hepatocytes is a concern; however, the ultimate answer to which of the $\mathrm{T}$ cells are more beneficial remains to be evaluated in vivo.

The analysis of $\mathrm{T}$ cell memory markers (Lamana et al. 2004) indicates that $T$ cells transduced under standard retroviral-mediated conditions differentiated fresh $\mathrm{CD} 8^{+}$ $\mathrm{CD} 4 \mathrm{RA}^{+} / \mathrm{CCR} 7^{+}$naïve cells to cells having a predominant central $\mathrm{CD}_{4} 5 \mathrm{RA}^{-} / \mathrm{CCR} 7^{+}$and effector $\mathrm{CD}^{2} 5 \mathrm{RA}^{-} /$ $\mathrm{CCR} 7^{-}$memory phenotype. One way to further rescue the population of naïve cells was by reducing the doses of antiCD3 antibodies at the activation stage. In addition, another way of improving the yield of central memory-like CD8 ${ }^{+}$ $T$ cells was recently developed (Yang et al. 2010, 2012). In those studies, central memory-like $\mathrm{CD} 8^{+} \mathrm{T}$ cells could be generated in clinical-scale using a simplified method based on lentiviral gene transfer, and the delivered antitumor TCR yielded up to 600fold expansion of CD8 T cells within 12 days. Importantly, they reported that specific cytokine combinations IL-12 plus IL-7 or IL-21 yielded the phenotype of $\mathrm{CD} 62 \mathrm{~L}^{\text {high }} \mathrm{CD} 28^{\text {high }} \mathrm{CD} 127^{\text {high }} \mathrm{CD} 27-$ ${ }^{~ h i g h} \mathrm{CCR} 7{ }^{\text {high }}$, which can be associated with lessdifferentiated $\mathrm{T}$ cells that resemble $\mathrm{T}_{\mathrm{CM}}$. Moreover, TCRengineered $\mathrm{CD}^{+} \mathrm{T}$ cells conferred specific antitumor activity and many displayed a central memory-like phenotype.

Given the current molecular technology and synthetic genetics, there is a large potential with this approach. Not only the expression, avidity and longevity of the TCRs that can be controlled in detail, but it is also possible to provide additional co-stimulatory receptors or tissue homing receptors to govern the strength of CTLs. Such modifications may also improve their capacity to home to infected cells and to deliver drugs in a site-specific manner. 
Rejuvenation by Induced Pluripotent Stem Cell Technology

Regeneration of antigen-specific $\mathrm{T}$ cells has recently been explored with induced pluripotent stem cells (iPSC) technology. After the discovery that somatic cells can be reprogrammed into iPSCs via the introduction of Yamanaka factors, this approach has not been subjected to same ethical concerns as that for embryonic stem cells (ESCs) (Takahashi and Yamanaka 2006). Similar to ESCs, iPSCs have the capacity for self-renewal and could potentially derive unlimited induction of antigen-specific juvenile $\mathrm{T}$ cells. Two stem cell groups have explored this novel approach to reprogram an exhausted immune system as treatment of cancer and chronic infection (Nishimura et al. 2013; Vizcardo et al. 2013). Both groups successfully established protocols to reprogram human antigen-specific $\mathrm{CD}^{+}$mature $\mathrm{T}$ cells ( $\mathrm{T}$ cell clones) into iPSCs. (Nishimura et al. (2013)) focused their work on HIV-specific $\mathrm{T}$ cells using Sendai virus vectors encoding reprogramming factors OCT3/4, SOX2, KLF4, and c-MYC or SV40 large $\mathrm{T}$ antigen. They managed to reprogram a clonally expanded HIV Nef-specific CD8 ${ }^{+}$CTL clone from a HIV-1infected patient to pluripotency and report the conditions they developed to reprogram several $\mathrm{CD}^{+}$or $\mathrm{CD}^{+}{ }^{+} \mathrm{T}$ cell clones that were specific for epitopes within the cytomegalovirus, glutamic acid decarboxylase antigen in type 1 diabetes, and $\alpha$-GalCer. It was revealed that $\mathrm{T}$ cell-derived iPSCs were re-differentiated into $\mathrm{CD}^{+} \mathrm{T}$ cells and showed a high proliferative capacity and elongated telomeres. Similar technology was used by Vizcardo et al. (2013) who showed that iPSCs could be produced from a mature CTL clone specific for the melanoma epitope MART-1. Longterm cultured tumor infiltrated lymphocytes derived from a melanoma patient were reprogrammed into iPSCs after sendai viral transduction with the four Yamanaka reprogramming factors, and could be further differentiated into functional IFN- $\gamma$ secreting MART- 1 reactive $\mathrm{CD}^{+} \mathrm{T}$ cells.

The strength with this approach is that iPSCs keep the ability to re-express its parental antigen-specific TCR. Both studies illustrated that the same productive of TCR gene rearrangement was found in all reprogrammed and re-differentiated $\mathrm{CD}^{+} \mathrm{T}$ cells. There was also evidence that such "rejuvenated" cells possessed antigen-specific killing activity and exhibited TCR gene rearrangement patterns identical to those of the original $\mathrm{T}$ cell clone from the patient (Nishimura et al. 2013). Furthermore, they showed that re-differentiation of these cells produced $\mathrm{CD}^{+} \mathrm{T}$ cells that recognized their original cognate antigen and had features of rejuvenated cells so critically needed to improve the efficacy of $\mathrm{T}$ cell-based therapies for the treatment of cancer and viral-associated diseases As a proof of concept, the results presented by these studies are exciting and more data are now warranted to justify the in vivo effect and safety of iPSCs technology.

\section{Conclusions}

The immune system is capable of achieving protective immunity and of inducing long-term, durable pathogenspecific responses. The use of adoptive $\mathrm{T}$ cell-based therapies to eradicate malignancies is a meaningful merger of basic immunology and clinical therapy that could have a therapeutic impact for $\mathrm{HCV}$ patient groups that are refractory of standard therapy. These may also serve in new therapeutic combinations, for instance with antiviral drugs to meet the potential challenges from resistant virus strains. Treatment for hepatitis $\mathrm{C}$ is moving forward, almost every week new data appear on how DAAs succeed or fail in clinical trials. Although encouraging data are constantly emerging, there are still hard-to-treat populations with poor rates of sustained virological response (SVR: cured infection); for instance, SVR rates in cirrhotic patients are only $47 \%$ (Gilead Sciences 2013). Importantly, with DAAs, viral resistance mutations are readily detected in the target protein, which explains the lack of efficacy once they occur. New treatment strategies with combinations of several DAAs will be used to overcome emergence of resistance; however, it has been questioned if such combinations will be tolerated (Sarrazin et al. 2012). Thus, novel interventions for hard-to-treat $\mathrm{HCV}$ patients are needed. With $\mathrm{T}$ cell therapy becoming a reality for cancer patients, it will also be possible to provide highly functional therapeutic $\mathrm{T}$ cells to $\mathrm{HCV}$ patients, regardless of their immune status to cure HCV-related liver disease in difficult-to-treat patient groups.

\section{References}

Abdel-Hakeem MS, Bedard N, Badr G et al (2010) Comparison of immune restoration in early versus late alpha interferon therapy against hepatitis C virus. J Virol 84:10429-10435

Alanio C, Lemaitre F, Law HK et al (2010) Enumeration of human antigen-specific naive CD8 $+\mathrm{T}$ cells reveals conserved precursor frequencies. Blood 115:3718-3725

Antia R, Ganusov VV, Ahmed R (2005) The role of models in understanding CD8 + T-cell memory. Nat Rev Immunol 5:101-111

Appay V, Douek DC, Price DA (2008) CD8 + T cell efficacy in vaccination and disease. Nat Med 14:623-628

Badr G, Bedard N, Abdel-Hakeem MS et al (2008) Early interferon therapy for hepatitis $\mathrm{C}$ virus infection rescues poly-functional, long-lived CD8 + memory T cells. J Virol 82:10017-10031

Bettini ML, Bettini M, Vignali DA (2012) T-cell receptor retrogenic mice: a rapid, flexible alternative to T-cell receptor transgenic mice. Immunology 136:265-272 
Bowen DG, Walker CM (2005) Adaptive immune responses in acute and chronic hepatitis $C$ virus infection. Nature 436:946-952

Callender GG, Rosen HR, Roszkowski JJ et al (2006) Identification of a hepatitis $\mathrm{C}$ virus-reactive $\mathrm{T}$ cell receptor that does not require CD8 for target cell recognition. Hepatology 43:973-981

Chen M, Sallberg M, Sonnerborg A et al (1999) Limited humoral immunity in hepatitis $\mathrm{C}$ virus infection. Gastroenterology 116:135-143

Chen M, Sallberg M, Thung SN et al (2000) Non-deletional T-cell receptor transgenic mice: model for the $\mathrm{CD} 4(+) \mathrm{T}$-cell repertoire in chronic hepatitis B virus infection. J Virol 74:7587-7599

Chen MT, Billaud JN, Sallberg M et al (2004) A function of the hepatitis $\mathrm{B}$ virus precore protein is to regulate the immune response to the core antigen. Proc Natl Acad Sci USA 101:14913-14918

Chen M, Sallberg M, Hughes J et al (2005) Immune tolerance split between hepatitis $\mathrm{B}$ virus precore and core proteins. J Virol 79:3016-3027

Ciuffreda D, Comte D, Cavassini M et al (2008) Poly-functional $\mathrm{HCV}$-specific T-cell responses are associated with effective control of HCV replication. Eur J Immunol 38:2665-2677

Dorner M, Horwitz JA, Robbins JB et al (2011) A genetically humanized mouse model for hepatitis $\mathrm{C}$ virus infection. Nature 474:208-211

Farci P, Alter HJ, Wong DC et al (1994) Prevention of hepatitis C virus infection in chimpanzees after antibody-mediated in vitro neutralization. Proc Natl Acad Sci USA 91:7792-7796

Farci P, Shimoda A, Wong D et al (1996) Prevention of hepatitis C virus infection in chimpanzees by hyperimmune serum against the hypervariable region 1 of the envelope 2 protein. Proc Natl Acad Sci USA 93:15394-15399

Garrone P, Fluckiger AC, Mangeot PE et al (2011) A prime-boost strategy using virus-like particles pseudotyped for $\mathrm{HCV}$ proteins triggers broadly neutralizing antibodies in macaques. Sci Transl Med 3: $94 \mathrm{ra} 71$

Ghany MG, Nelson DR, Strader DB et al (2011) An update on treatment of genotype 1 chronic hepatitis $C$ virus infection: 2011 practice guideline by the American association for the study of liver diseases. Hepatology 54:1433-1444

Giang E, Dorner M, Prentoe JC et al (2012) Human broadly neutralizing antibodies to the envelope glycoprotein complex of hepatitis C virus. Proc Natl Acad Sci USA 109:6205-6210

Gilead Sciences (2013) Results from Gilead phase 3 trials with Sofosbuvir. Available at http://wwwhepctrustorguk/News Resources/news/2013/January/Results +from+Gilead+phase+ $3+$ trials + with + sofosbuvir

Grakoui A, Shoukry NH, Woollard DJ et al (2003) HCV persistence and immune evasion in the absence of memory $\mathrm{T}$ cell help. Science 302:659-662

Guidotti LG, Chisari FV (2001) Non cytolytic control of viral infections by the innate and adaptive immune response. Annu Rev Immunol 19:65-91

Guidotti LG, Rochford R, Chung J et al (1999) Viral clearance without destruction of infected cells during acute HBV infection. Science 284:825-829

Jacobson IM, McHutchison JG, Dusheiko G (2011) Telaprevir for previously untreated chronic hepatitis $\mathrm{C}$ virus infection. $\mathrm{N}$ Engl J Med 364:2405-2416

Kim PS, Ahmed R (2010) Features of responding T cells in cancer and chronic infection. Curr Opin Immunol 22:223-230

Klebanoff CA, Gattinoni L, Restifo NP (2006) CD8 + T-cell memory in tumor immunology and immunotherapy. Immunol Rev 211:214-224

Klebanoff CA, Gattinoni L, Palmer DC et al (2011) Determinants of successful CD8 + T-cell adoptive immunotherapy for large established tumors in mice. Clin Can Res 17:5343-5352
Klenerman P, Thimme R (2012) T cell responses in hepatitis C: the good, the bad and the unconventional. Gut 61:1226-1234

Lamana ML, Bueren JA, Vicario JL et al (2004) Functional and phenotypic variations in human $\mathrm{T}$ cells subjected to retroviralmediated gene transfer. Gen Ther 11:474-482

Law M, Maruyama T, Lewis J et al (2008) Broadly neutralizing antibodies protect against hepatitis $\mathrm{C}$ virus quasispecies challenge. Nat Med 14:25-27

Lechner F, Wong DK, Dunbar PR et al (2000) Analysis of successful immune responses in persons infected with hepatitis $\mathrm{C}$ virus. J Exp Med 191:1499-1512

Logvinoff C, Major ME, Oldach D et al (2004) Neutralizing antibody response during acute and chronic hepatitis $\mathrm{C}$ virus infection. Proc Natl Acad Sci USA 101:10149-10154

Nakamoto N, Kaplan DE, Coleclough J et al (2008) Functional restoration of $\mathrm{HCV}$-specific $\mathrm{CD} 8 \mathrm{~T}$ cells by $\mathrm{PD}-1$ blockade is defined by PD-1 expression and compartmentalization. Gastroenterology 134:1927-1937

Netski DM, Mosbruger T, Depla E et al (2005) Humoral immune response in acute hepatitis $\mathrm{C}$ virus infection. Clin Inf Dis 41:667-675

Neumann-Haefelin C, Timm J, Spangenberg HC et al (2008) Virological and immunological determinants of intrahepatic virus-specific $\mathrm{CD} 8+\mathrm{T}$-cell failure in chronic hepatitis $\mathrm{C}$ virus infection. Hepatology 47:1824-1836

Nishimura T, Kaneko S, Kawana-Tachikawa A et al (2013) Generation of rejuvenated antigen-specific $\mathrm{T}$ cells by reprogramming to pluripotency and redifferentiation. Cell Stem Cell 12: $114-126$

Pasetto A, Frelin L, Aleman S et al (2012a) TCR-redirected human T cells inhibit hepatitis $\mathrm{C}$ virus replication: hepatotoxic potential is linked to antigen specificity and functional avidity. J Immunol 189:4510-4519

Pasetto A, Frelin L, Brass A et al (2012b) Generation of T-cell receptors targeting a genetically stable and immunodominant cytotoxic T-lymphocyte epitope within hepatitis $\mathrm{C}$ virus nonstructural protein 3. J Gen Virol 93(Pt 2):247-258

Radziewicz H, Ibegbu CC, Fernandez ML et al (2007) Liverinfiltrating lymphocytes in chronic human hepatitis $\mathrm{C}$ virus infection display an exhausted phenotype with high levels of PD1 and low levels of CD127 expression. J Virol 81:2545-2553

Radziewicz H, Ibegbu CC, Hon H et al (2008) Impaired hepatitis C virus $(\mathrm{HCV})$-specific effector $\mathrm{CD} 8+\mathrm{T}$ cells undergo massive apoptosis in the peripheral blood during acute HCV infection and in the liver during the chronic phase of infection. J Virol 82:9808-9822

Rehermann B (2009) Hepatitis C virus versus innate and adaptive immune responses: a tale of coevolution and coexistence. J Clin Inv 119:1745-1754

Rehermann B, Nascimbeni M (2005) Immunology of hepatitis B virus and hepatitis $C$ virus infection. Nat Rev Immunol 5:215-229

Restifo NP, Dudley ME, Rosenberg SA (2012) Adoptive immunotherapy for cancer: harnessing the $\mathrm{T}$ cell response. Nat Rev Immunol 12:269-281

Sallusto F, Geginat J, Lanzavecchia A (2004) Central memory and effector memory $\mathrm{T}$ cell subsets: function, generation, and maintenance. Annu Rev Immunol 22:745-763

Sarrazin C, Hezode C, Zeuzem S et al (2012) Antiviral strategies in hepatitis C virus infection. J Hepatol 56(Suppl 1):S88-S100

Schmidt J, Neumann-Haefelin C, Altay T et al (2011) Immunodominance of HLA-A2-restricted hepatitis $\mathrm{C}$ virus-specific CD8 $+\mathrm{T}$ cell responses is linked to naive-precursor frequency. $\mathrm{J}$ Virol 85:5232-5236

Spangenberg HC, Viazov S, Kersting N et al (2005) Intrahepatic $\mathrm{CD} 8+\mathrm{T}$-cell failure during chronic hepatitis $\mathrm{C}$ virus infection. Hepatology 42:828-837 
Takahashi K, Yamanaka S (2006) Induction of pluripotent stem cells from mouse embryonic and adult fibroblast cultures by defined factors. Cell 126:663-676

Thimme R, Oldach D, Chang KM et al (2001) Determinants of viral clearance and persistence during acute hepatitis $\mathrm{C}$ virus infection. J Exp Med 194:1395-1406

Vizcardo R, Masuda K, Yamada D et al (2013) Regeneration of human tumor antigen-specific $\mathrm{T}$ cells from iPSCs derived from mature CD8(+) T cells. Cell Stem Cell 12:31-36

Wang A, Chandran S, Shah SA et al (2012) The stoichiometric production of IL-2 and IFN-gamma mRNA defines memory T cells that can self-renew after adoptive transfer in humans. Sci Transl Med 4: 149ra120

Wherry EJ (2011) T cell exhaustion. Nat Immunol 12:492-499
Yang S, Dudley ME, Rosenberg SA et al (2010) A simplified method for the clinical-scale generation of central memory-like CD8 $+\mathrm{T}$ cells after transduction with lentiviral vectors encoding antitumor antigen T-cell receptors. J Immunother 33:648-658

Yang S, Ji Y, Gattinoni L et al (2012) Modulating the differentiation status of ex vivo-cultured anti-tumor $\mathrm{T}$ cells using cytokine cocktails. Cancer Immunol Immunother 62:727-736

Zhang Y, Liu Y, Moxley KM et al (2010) Transduction of human T cells with a novel T-cell receptor confers anti-HCV reactivity. PLoS Pathog 6:e1001018

Zimmerli SC, Harari A, Cellerai C et al (2005) HIV-1-specific IFNgamma/IL-2-secreting CD8 T cells support CD4-independent proliferation of HIV-1-specific CD8 T cells. Proc Natl Acad Sci USA 102:7239-7244 